\title{
Integrating Management Competencies Development with an Organizational Culture Formation
}

\author{
Karel Pavlica', Eva Jarošová2, Robert B. Kaiser ${ }^{3}$
}

\author{
1Škoda Auto University, Department of Managerial Psychology and Sociology, Na Karmeli 1457, 29301 Mladá Boleslav, \\ Czech Republic, karel.pavlica@skoda-auto.cz \\ ${ }^{2}$ University of Economics, Prague, Department of Managerial Psychology and Sociology, W. Churchilla 4, 13067 Prague 3, \\ Czech Republic, evajar@vse.cz \\ ${ }^{3}$ Kaiser Leadership Solutions, 1903-G Ashwood Ct., Greensboro, NC, USA 27455, rkaiser@kaiserleadership.com
}

\begin{abstract}
The paper presents the first results of the IGA/2012/7 project "Versatility of Organizational Management and its Reflection in the Area of Organizational Culture". The paper tries to answer in particular a question if there exist and what are the relations between a process of management competencies development and process of organizational culture creation and change. The research is based upon two methods: (1) Leadership Versatility Index® (LVI®) and Denison Organizational Culture Survey (DOCS). The research data are presented in a form of two cases. Qualitative analysis of these data has led to two preliminary conclusions: (1) Some of the research expectations concerning an existence of the relations between organization's management versatility and organizational culture might be confirmed in a future; (2) DOCS data can bring a new light on the LVI@ results and on the process of management competencies development. They help managers to understand that a change and development of their management competencies is not their personal business but a need with important strategic consequences for the whole organization. Reliable answers to all research questions and hypothesises are conditioned by a statistical analysis of the data collected in more organizations, however.
\end{abstract}

Key words: leadership, management, versatility, organizational culture, competencies development

\section{Introduction}

This paper presents the first results of a three years long research project focused on an identification of the relationships between organizations' management versatility and organizational culture. As such it is based upon the findings (i.e. Morgan 1986, Holland 1997; Hogan 2006, Kaiser and Overfield, 2010, Hartnell et al., 2011) about an existence of the relationships between personality of the key organizational managers and inner organizational environment. On a theoretical level the project refers to the two conceptions: (1) theory of versatile leadership (i.e. Kaplan and Kaiser 2006; Pavlica et al. 2010) which represents a new original approach to leadership definition as well as to management competencies measurement and development; (2) Denison's dynamic model of organizational culture (Denison et al. 2012). These approaches will be described in a more detailed way in chap- ter 2 (Methods). On a more practical level this project tries to integrate and harmonize a process of managers' competencies development with a process of organizational culture management.

History offered us tens of the different views of leadership in organizations, however only a limited number of these theories have found a wider application in companies during the past 40 years.

- Contingency approach. As its main authors are usually presented Vroom and Yetton (Osland et al., 2001). As the main ambition and goal of this approach can be seen an attempt to define principles and rules determining effectiveness of the different leadership styles. This theory has uprooted a myth about an existence of one optimum leadership style.

- Approaches based upon cross-cultural research. As their "father" has been identified Dutch psychologist Hofstede (Gatley et al., 1996). The main contribution of Hofstede

Received: $20^{\text {th }}$ August 2013; revised: $5^{\text {th }}$ September 2013; accepted: $30^{\text {th }}$ September 2013 
and his followers rests in a demonstration of the relations between particular leadership styles effectiveness and a wider cultural environment.

- Situational leadership theory which has been usually associated with Hersey and Blanchard (1993). This conception stresses a need to base a management and development of the employees upon a systematic assessment of their personal and professional maturity.

- Coaching which has become strongly influential during the two past decades (i.e. Whitmore 2009). This view stresses a need to approach different social subjects (individuals, groups and organizations) as autonomous entities which are themselves capable to manage effectively both their (personal) problems and the process of their own development and learning.

- Paradox approach (also "Competing Values Framework") proposed in 80-ies of the past century by an American sociologist Quinn (Osland et al., 2001, Kaiser and Overfield 2010). Quinn argued that conflicting needs (orientation towards human relations VS towards rational goals; focus on internal processes VS focus on opening the system to external affects) are inherent in complex organizations.

- $360^{\circ}$ feedback methodology which has been used widely during the past decade. This approach tries to incorporate objectivity into the process of leadership effectiveness measurement. Managers are usually evaluated by their superiors, colleagues and subordinates.

All of the conceptions listed above have delivered several important "messages"about leadership:

- Particular effectiveness of each leadership style is always conditioned by a complex of the different external - culture, organization, situation at hand, employees etc. - factors.

- Managers' attention to and evaluation of the external conditions should be combined with an individual approach to employees.

- Coaching represents a useful leadership and staff development technique.

- Each management style/behavior has its "competing"//"conflicting" however functional opposite. Different managerial approaches and techniques should be combined in a flexible and to a specific context/situation responsive way.

- The process of an organization's management competencies development becomes more effective when it refers to the results of the instruments providing a feedback mediated by different groups of social actors - managers' superiors, colleagues, subordinates etc.

Regardless to their value and contribution it is possible to identify also some of the limitations and liabilities of the popular leadership theories and approaches:

- Sometimes too complicated and abstract recommendations and techniques. This is obvious in particular on a contingency approach.

- Simplified perception of managerial work and role - i.e. common attempts to "squeeze" managers into one of the traditional leadership styles (autocratic, democratic, liberal etc.). These attempts are based on a belief in an existence of a "typical" model of an individual behaviour. Several important facts have been ignored in this respect, however: (1) Psychological research demonstrates that an occurrence of the "pure" types is rare - majority of the population fall within the so called "mixed" types. (2) In a long-term perspective each individual behaves contradictory - even the most outstanding autocrat can behave as a liberal sometimes and the opposite. (3) Styles tend to be defined in a contrast way as mutually self-exclusive alternatives. Within each of them it is possible to apply the same conducts and skills, however - i.e. a fact that a certain manager has been labelled as an "autocrat" does not mean necessarily that he/she cannot listen or discuss as an "liberal" or "democrat".

- Predominantly behaviouristic view of the managerial competencies as the conducts independent on manager's personality and organizational context.

Conception of versatile leadership refers to tried elements of the approaches listed above (in particular to Competing Values Framework and Situational leadership) and offers a promising alternative for overcoming their main limitations. It points to a fact that today's managers work in a complex world. Every decision can be a trade-off in an economy fraught with paradoxical demands: Companies we compete with in one arena may be our partners in another. Maximizing profits today often conflicts with investing in tomorrow. The need to produce can clash with concern for people and human limits. To be up to the task, managers must be equally complex in their leadership (Pavlica et al., 2011).

Being a complex leader boils down to the ability to play multiple roles, even contradictory ones, without emphasizing some at the expense of others. Versatility means the ability to use opposing approaches, unrestricted by a bias in favour of some ways of leading and a prejudice against others. Versatile leadership can be seen also as a new way of understanding flexibility - "adjusting one's leadership style, methods, or approach in response to different or changing contextual demands in a way that facilitates group performance" (Kaiser and Overfield, 2010: 106) - in the area of management and leadership.

The extent to which managers are versatile is highly related to a team effectiveness. Statistical studies show that average versatility - effectiveness multiple correlation is $\mathrm{R}$ $=0,71$, squaring this result leads to $\mathrm{R}^{2}=0,50$. This means that versatility accounts for half of what separates the most well-regarded leaders from the least well-regarded (Kaiser and Kaplan 2007). A degree of manager's versatility also positively correlates with a long-term success in his/her career (Kaplan and Kaiser, 2006, Pavlica et al., 2010).

The second theoretical underlying stone of our project is represented by Denison's view of organizational culture. Also this approaches refers to the Quinn's Competing Values Framework and as such it can be conceptually related to the versatile view of leadership. Denison and his team (Denison et al., 2012) has tried to understand the cultural traits that explain the difference between high- and low-performing organiza- 
tions. Their studies have led to a proposal of a dynamic model which helps to identify both deficits and imbalances in the area of organizational culture.

In reference to the facts presented above this project tries to answer the following basic questions.

- "Long term research conducted by the authors of the versatile leadership conception proves significant relation between managers' versatility and effectiveness (productivity and vitality) of their teams. Is it possible to identify also relations between the versatility of the key organizational managers and organizational culture as it has been defined and measured by the Denison's model of organizational culture?"“

- "What are the differences between cultures in organizations managed by versatile and lopsided managers?"

- "Does it make sense to integrate a process of management competencies development with a process of organizational culture formation and change?"

The research data we have collected and analysed during the first year of the project are offering a partial answer to the last basic question.

\section{Methods}

As was mentioned above this part of our paper offers more detailed descriptions of the versatile leadership conception and of the Denison's model of organizational culture, including unique research techniques based upon these approaches. After this additional research questions and expectations are articulated.

As it has been indicated before, versatility represents a way which thinks about leadership in terms of pairs of opposites, opposing forces that are both useful and complementary (Kaplan and Kaiser, 2006; Pavlica et al., 2010). Many opposing dimensions of leadership have been identified over the years: autocratic vs. democratic, task-oriented vs. people-oriented, initiative vs. consideration, change vs. stability, transformational vs. transactional, and so on. Common to these pairings is that each side is an important function that has its place in effective leadership. "Either/or" won't do; organizations require leaders to be "both/and" when it comes to these opposing ways of leading.

Two broad distinctions have been joined to provide an inclusive model of opposites that make up managerial work. First is John Kotter's classic distinction between leadership versus management. Kotter described management as "doing things right" and achieving efficiency and predictability through command and control. In contrast, he portrayed leadership as "doing the right things" and inspiring people with a vision of change.

A second broad distinction is between the interpersonal aspects of leadership and the organizational aspects of leadership. The interpersonal part concerns "how" one leads, and largely revolves around a self-assertive, directive style versus a more inclusive, supportive style. The organizational part concerns "what" one leads and revolves around the technical and tactical details of execution in the short-term versus plan- ning ahead to position the organization or team with a strategy for the future.

Combining the Management versus Leadership distinction with the "How" versus "What" distinction leads to the model of opposing behaviors (Kaiser and Overfield, 2010) presented below (see Figure 1).

Degree of managers' versatility is measured by the means of $360^{\circ}$ feedback tool Leadership Versatility Index ${ }^{\circledR}$ (LVI $\left.{ }^{\circledR}\right)$.

Most of the existing 360s use 5-point rating scales. Their problem is that they do not indicate when managers do something too much. Instead, they seem to assume that „more is better" and imply that a high score is the best score. Furthemore they do not tease apart overdoing it and underdoing it as distinct sources of ineffectiveness.

To remedy this problem a new rating scale (curvilinear scale, see Figure 2) was developed. It ranges from -4 to +4 . Values from -4 to -1 represent degrees of "too little" (deficits in manager's conduct), values from +1 to +4 represent degrees of "too much" (excesses in manager's behaviour). Ratings 0 represent "right amount" of a particular managerial behavior, approach or technique (Kaiser and Kaplan, 2007).

\begin{tabular}{|c|c|c|}
\hline & $\begin{array}{l}\text { Management } \\
\text { Achieving effi- } \\
\text { ciency through } \\
\text { command and } \\
\text { control }\end{array}$ & $\begin{array}{c}\text { Leadership } \\
\text { Inspiring people } \\
\text { with vision and } \\
\text { change }\end{array}$ \\
\hline $\begin{array}{c}\text { Interpersonal } \\
\text { "How" }\end{array}$ & $\begin{array}{c}\text { Self-assertive } \\
\text { and directive } \\
\text { Takes charge } \\
\text { Declares } \\
\text { Pushes }\end{array}$ & $\begin{array}{c}\text { Inclusive and } \\
\text { supportive } \\
\text { Empowers } \\
\text { Listens } \\
\text { Supports }\end{array}$ \\
\hline $\begin{array}{c}\text { Organizational } \\
\text { „What" }\end{array}$ & $\begin{array}{c}\text { Short-term, } \\
\text { operational } \\
\text { Execution } \\
\text { Efficiency } \\
\text { Order }\end{array}$ & $\begin{array}{c}\text { Long-term, } \\
\text { strategic } \\
\text { Direction } \\
\text { Growth } \\
\text { Innovation }\end{array}$ \\
\hline
\end{tabular}

Figure 1. A model of opposing behaviors

\begin{tabular}{|c|c|c|c|c|c|c|c|c|}
\hline \multirow{2}{*}{$\begin{array}{l}\leftarrow \\
\mathrm{o}\end{array}$} & \multicolumn{2}{|c|}{ Too little } & $\leftarrow$ & \multirow{2}{*}{$\begin{array}{c}\begin{array}{c}\text { The } \\
\text { right } \\
\text { amount }\end{array} \\
\text { o }\end{array}$} & $\rightarrow$ & \multicolumn{2}{|c|}{ Too much } & $\rightarrow$ \\
\hline & o & 0 & o & & o & 0 & 0 & o \\
\hline-4 & -3 & -2 & -1 & 0 & +1 & +2 & +3 & +4 \\
\hline
\end{tabular}

Figure 2. Curvilinear rating scale

In accordance to a model of opposing behaviours the LVI ${ }^{\circledR}$ measures manager's versatility along two dimensions represented by opposites between: (1) Self-assertive, directive and Inclusive, supportive behaviour; (2) Short-term executive/ operational and Long-term strategic behaviour. Each pole is represented by 12 items, the whole technique contains 24 pairs of opposing statements - descriptions of specific managerial behaviours (i.e. Pushes people hard vs Shows appreciation; Future oriented vs Results oriented). LVI ${ }^{\circledR}$ measures also managers's effectiveness in terms of a productivity (volume 
and quality of the outputs) and vitality (morale, engagement with work and group cohesiveness) of his/her team.

Research with the LVI® also shows that truly wellrounded and versatile managers are in the minority. Versatility scores are percentages that can be interpreted like letter grades in school, where higher percentages indicate mastery: $90 \%$ A, $80 \%$ B, $70 \%$ C etc. The average versatile score in Kaplan DeVries Inc. normative database (with ratings for 1123 senior managers) is $81 \%$, a low B (Kaiser and Kaplan, 2007). In fact, just over half of managers get B's and about $40 \%$ get lower than a $\mathrm{B}$, while only $6 \%$ get an A (see Figure 3 ).

There exist two possible general reasons explaining why do so many managers lack versatility. It may be that leadership is like any other skilled performance; it takes talent, years of practice, hard work and concentrated study to master. It also may be that a new paradigm of leadership is emerging to deal with increased complexity and a faster pace of change and this requires multifaceted managers like never before. Either way, the next question is how can managers expand their repertoire and become more versatile leaders? A key to the solution is an assessment tool that identifies how versatile the leader is now, including clear strenghts, strenghts overused, as well as shortcomings. This is precisely what LVI ${ }^{\circledR}$ was designed to do.

\begin{tabular}{|c|c|}
\hline Overall Versatility & Percentage of Managers \\
\hline $90 \%-100 \%$ & $6,1 \%$ \\
\hline $80 \%-90 \%$ & $54,4 \%$ \\
\hline $70 \%-80 \%$ & $31 \%$ \\
\hline $60 \%-70 \%$ & $7,5 \%$ \\
\hline Below $60 \%$ & $1 \%$ \\
\hline
\end{tabular}

Figure 3. Distribution of Versatility Scores

Much of modern management development is based on behaviorism. These approaches start and end with behavior: behavior-based assessment, behavior modeling, behavior based peformance coaching, and so forth. Of course, behavior is the bottom line when it comes to performance. Performance, however, isn't a matter of behavior alone; it is also the product of mindset and emotion (Hogan and Kaiser, 2005; Hogan, 2006).

The LVI ${ }^{\circledR}$ is ideally suited for setting up both the outer work and the inner work of development.

The outer work of development involves directly changing behavior. In the case of something a manager does too little, the needed chnage is to do more. This may involve an element of coercion because manager must make himself do something he has neglected or avoided. In the case of "overkill", the needed change is to do less. This requires manager to ease up and be more selective.

Direct attempts to change behavior may only go so far. The next question is, then why does the troublesome behavior persist? The reasons given may be things "out there" in the work environment, but more leverage may be "inside" the manager. Growing as a leader often hinges on growing as a person (Kaplan and Kaiser, 2006).
Personal development means that the path to improving one's leadership may require a thoughtful examination of basic beliefs and emotional investments. It can start with a few simple, ever so practical questions: Why do you do too much here - what compels you? Why do you do toolittle there - what holds you back? Experience shows, that behind a lopsided leadership there often is:

- Crooked thinking. Some managers have an incomplete and/or incorrect understaning of their job. They are aware of only one side of the "whole story" - they may believe in the need to achieve the results while overlooking the people side, for example.

- Faulty gauges. Some managers have a trouble judging how much is too much. Just as a broken thermostat can overheat or chill a room, a faulty gauge can cause a leader to go overboard, or come up short.

- Polarized values. Lopsided leadership often rests on polarized values, where one side is idealized and the other is devalued. On one hand, some managers can't imagine such a thing as too much of something they believe in. Consequently, they are liable to overdo it. On the other hand, they will often disparage the complementary approach.

- Fears. There can be a fear on the part of overly directive individuals of not being powerful enough that produces the excess. And there can be a fear on the part of overly supportive managers, of becomming an exaggerated version of forcefulness, as if moving in that direction means being arrogant, rude or abrasive.

- Unrecognized strenghts. Some people may fail to appreciate their own strenghts, either in terms of particular skill or one's capability in general. Underrating oneself can compel a manager to try too hard to compensate; underestimate, overdo. It can also prompt an individual to avoid certain tasks for fear of not performing well; underestimate, underdo.

Versatile leadership conception represents a progressive approach which inspires further research activities. One of them is represented in our project by an attempt to apply an idea of versatility on a wider organizational scale, in particular to analyse what are the relations between management's versatility (and consequently management competencies) and organizational culture.

After discussing our project's aims with both our research colleagues from Kaplan DeVries Inc. and experts from Denison Consulting (see Acknowledgements), we have decided to use Denison Organizational Culture Survey (DOCS) as an appropriate method for organizational culture analysis.

Studies conducted by Denison and his colleagues (Denison et al, 2012) have identified the four basic traits of organizational culture - mission (sense of purpose and direction that allows to define organizational goals and strategies), adaptability (degree of flexibility and responsiveness to business environment), involvement (commitment of all organizational members to work and goals), and consistency (set of core values, rules and practices that coordinate and integrate behaviour of organizational members). These basic traits can be linked to different performance measures such 
as profitability, sales growth, quality, innovation, and market value. Out of these studies an original way to measure culture - DOCS - was developed.

Like a versatile view of leadership also Denison's model of organizational culture focuses on a set dynamic contradictions/tensions that must be managed. In particular DOCS highlights four such tensions: (1) the trade-off between stability and flexibility; (2) the trade-off between internal and external focus; (3) tension between internal consistency and external adaptability; (4) tension between mission and involvement (Denison et al., 2012).

The core of DOCS is a sixty-item survey, with fifteen questions about each trait (all traits are defined by the means of three indexes - see Figure 4). The survey uses five-point Likert scale in which $1=$ strongly disagree and $5=$ strongly agree. Research shows (Denison et al., 2012) that an effective organization scores high on all traits and indexes.

\begin{tabular}{|c|c|c|}
\hline External focus & $\begin{array}{l}\text { Adaptability } \\
\text { - Creating change } \\
\text { - Customer focus } \\
\text { - Organizational } \\
\text { learning }\end{array}$ & $\begin{array}{l}\frac{\text { Mission }}{\text { - Strategic direc- }} \\
\quad \text { tion } \\
\text { - Goals } \\
\text { - Vision }\end{array}$ \\
\hline Internal focus & $\begin{array}{l}\text { Involvement } \\
\text { - Empowerment } \\
\text { - Team orientation } \\
\text { - Capability devel- } \\
\text { opment }\end{array}$ & $\begin{array}{l}\text { Consistency } \\
\text { - Core values } \\
\text { - Agreement } \\
\text { - Coordination/ } \\
\text { integration }\end{array}$ \\
\hline & \multicolumn{2}{|c|}{$\begin{array}{ll}\text { Flexible } & \text { Stable }\end{array}$} \\
\hline
\end{tabular}

Figure 4. DOCS model of organizational culture

Keeping the basic questions (see Introduction) in mind an additional research question has been formulated:

- "Which DOCS traits and indexes correlate with an overall managers' versatility? Which DOCS traits and indexes correlate with partial managers' versatility, represented by scores for directive VS supportive, and operational VS strategic leadership?“

In respect to the nature and content of LVI ${ }^{\circledR}$ and DOCS also four working hypothesises have been proposed:

- We expect that organizations with highly versatile management (average versatility indexes values 85\% and above) will score high (average values 4,0 and above) also on DOCS traits and indexes. At the same time we expect that organizations with lopsided management (average versatility indexes values $70 \%$ and below) will score low (average values 2,5 and below) on DOCS traits and indexes.

- We expect positive correlations between overall management versatility and DOCS traits and indexes values.

- We expect positive correlations between the scores for partial versatility on a dimension long-term (strategic) VS short-term (operational) leadership and the values for the DOCS traits mission, adaptability and consistency.
- We expect positive correlations between the scores for partial versatility on a dimension directive VS supportive leadership and the values for the DOCS trait involvement.

The whole project has been scheduled for a period of three years. It has started in June 2012 and should be finished in June 2015. The data will be collected in the large and middle size organizations operating on a Czech market. Both methods LVI ${ }^{\circledR}$ and DOCS were translated to Czech by the back translation technique.

\section{Results}

In June 2013 a basic analysis of the data collected in two middle organizations was finished. On one hand it is too little information for answering all of our research questions and working hypothesises. On the other hand these data can illustrate how the processes of management competencies development an organizational culture management fit together.

The results are presented in a form of two short cases. In each of these cases the research team proceeded in the following way:

- Initial workshop with the members of an organization's top management. During this the goals of the project (including what are the potential practical benefits for a company) and nature of LVI ${ }^{\circledR}$ and DOCS were explained.

- Data collection. The LVI ${ }^{\circledR}$ was applied on a sample of top managers. After this DOCS was distributed to all employees and managers of an organization.

- Workshop focused on the LVI ${ }^{\circledR}$ results. First, group of managers participating in the project were explained how to understand the LVI ${ }^{\circledR}$ results. Second, researchers provided all of the managers with individual coaching interview focused on in depth understanding of received LVI ${ }^{\circledR}$ reports as well as on an identification of the key personal strengths and weaknesses (deficits and excesses in the area of leadership and management competencies). At the end of the interview the managers were asked to prepare the personal development plans.

- Final workshop focused on the DOCS results presentation as well as on an identification of their links to the data obtained by the means of the LVI ${ }^{\circledR}$.

\section{Case 1: Mechanical Engineering Company}

The first organization we have analysed was a Czech branch of an international mechanical engineering company. It employs more than 100 people and its top management is represented by 9 people. The company operates on a Czech market for more than ten years. A new young director has been appointed (the former one retired) when we established initial contacts and cooperation with its management. A major ambition of a new director was to make "his" organization more competitive and autonomous. Together with the HR manager he appreciated an offer to participate in our research project as an opportunity to get a qualified feedback about organization's and its management developmental potential and needs.

As the first technique was applied the LVI® on a sample of 9 managers. There average experience with managerial position and work is 5 years (minimum 2 years, maximum 11 
years) what indicates that the management team is relatively young. Figure 5 shows the average LVI ${ }^{\circledR}$ scores for the group.

\begin{tabular}{|c|c|c|c|}
\hline & $\begin{array}{c}\text { Overall } \\
\text { versatility }\end{array}$ & $\begin{array}{c}\text { Directive/ } \\
\text { supportive } \\
\text { versatility }\end{array}$ & $\begin{array}{c}\text { Operational/ } \\
\text { strategic } \\
\text { versatility }\end{array}$ \\
\hline $\begin{array}{c}\text { Group } \\
\text { average }\end{array}$ & $82 \%$ & $80 \%$ & $83 \%$ \\
\hline
\end{tabular}

Figure 5. Average versatility scores of the managers from organization 1

According to these data the organization's management team versatility scores are neither "excellent" nor "poor". Normative database (see Methods) shows that the scores between $80 \%-90 \%$ are the most common among the managers. This organization's management team as a whole definitely has a potential to be successful and effective in a future.

The lowest score $(80 \%)$ was reached for a dimension Self-assertive, directive VS Inclusive, supportive leadership. This indicates that probably the major challenges in the area of the management competencies development are associated with "how" the managers approach and lead their staff. A deeper insight into this area can offer us an overview of the major excesses (see Figure 6) and deficits (see Figure 7). As a major excess was understood an item on which a manager was rated by all his/her co-workers (superiors, colleagues, subordinates) by a value 1 and above on average. As a major deficit was understood an item on which a manager was rated by all his/her co-workers (superiors, colleagues, subordinates) by a value - 1 and below on average. Letter indexes on items have the following meaning: $\mathrm{f}=$ item represents directive, $\mathrm{e}=$ item represents supportive, $\mathrm{o}=$ item represents operational, $\mathrm{s}$ $=$ item represents strategic pole of leadership.

\begin{tabular}{|l|c|}
\hline Item & Frequency \\
\hline $\begin{array}{l}\text { 8f: Defends his/her position - doesn't back } \\
\text { down easily. (Declares) }\end{array}$ & $\mathbf{3}$ \\
\hline 9f: Pushes people hard. (Pushes) & $\mathbf{2}$ \\
\hline $\begin{array}{l}\text { 2f: Takes the initiative - seizes the opportu- } \\
\text { nity to lead. (Takes charge) }\end{array}$ & $\mathbf{2}$ \\
\hline $\begin{array}{l}\text { 3f: Sets clear expectations - tells people } \\
\text { what to do. (Takes charge) }\end{array}$ & $\mathbf{1}$ \\
\hline $\begin{array}{l}\text { 3e: Gives people the latitude to decide how } \\
\text { to do their jobs - hands-off. (Empowers) }\end{array}$ & $\mathbf{1}$ \\
\hline
\end{tabular}

Figure 6. The major excesses within a management team of organization 1

All of the major excesses fall within a dimension directive / supportive leadership. Eight (8) out of nine (9) strong excesses represent a pole of Self-assertive, directive approach to people. When related to general areas of management competencies these results show that some members of the management team tend to "declare" themselves too much (as the opposite to competence of "listening"), tend to "take charge" too much (as the opposite to competence of "empowering" people) and tend to "push" people too much (as the opposite to competence of "supporting").

\begin{tabular}{|l|c|}
\hline Item & Frequency \\
\hline $\begin{array}{l}\text { 5s: Expansive - aggressive about growing } \\
\text { the business. (Growth) }\end{array}$ & $\mathbf{4}$ \\
\hline $\begin{array}{l}\text { 6s: Ambitious to improve the organiza- } \\
\text { tion - launches many change initiatives } \\
\text { (Growth) }\end{array}$ & $\mathbf{3}$ \\
\hline 7s: Willing to make bold moves. (Growth) & $\mathbf{3}$ \\
\hline $\begin{array}{l}\text { 1s: Spends time and energy on long-term } \\
\text { planning - future oriented (Direction) }\end{array}$ & $\mathbf{2}$ \\
\hline $\begin{array}{l}\text { 2s: Thinks strategically - takes a high level } \\
\text { view of where the unit is going. (Direction) }\end{array}$ & $\mathbf{2}$ \\
\hline $\begin{array}{l}\text { 6e: Draws people out - wants to know } \\
\text { where they stand. (Listens) }\end{array}$ & $\mathbf{2}$ \\
\hline $\begin{array}{l}\text { 11e: Sensitive - careful not to hurt the } \\
\text { other person's feelings (Supports) }\end{array}$ & $\mathbf{2}$ \\
\hline $\begin{array}{l}\text { 5e: Participative - includes people in mak- } \\
\text { ing decisions. (Listens) }\end{array}$ & $\mathbf{1}$ \\
\hline $\begin{array}{l}\text { 7e: Open to influence - can be persuaded } \\
\text { to change his/her mind. (Listens) }\end{array}$ & $\mathbf{1}$ \\
\hline $\begin{array}{l}\text { 3e: Gives people the latitude to decide how } \\
\text { to do their jobs - hands-off. (Empowers) }\end{array}$ & $\mathbf{1}$ \\
\hline 9f: Pushes people hard. (Pushes) & $\mathbf{2}$ \\
\hline
\end{tabular}

Figure 7. The major deficits within a management team of organization 1

Most of the deficits (14) represent competencies associated with strategic leadership. Members of the management team tend to be (10 cases) too little oriented on organization's "growth"(as the opposite to operational orientation on "efficiency") and (4 cases) too little concerned with "directing" an organization towards future perspectives (as the opposite of operational orientation on "execution" and immediate results). Four (4) identified strong deficits are associated with "listening" to people correspond to excesses in the area of ,declaring"- being too decisive, forthcoming and even stubborn. Two otter deficits are associated with "supporting" people and one with "empowering" - this also reflects an identified overuse of the approaches based on directive and self-assertive leadership.

Two managers have troubles with "pushing" people towards personal responsibility and high performance. During the coaching interviews we found out, however, that this overall low rating on an item 9f is probably a result of their unequal approach to people. Because of different reasons they tend to be too protective towards some of their subordinates while at the same time they treat the rest (majority) of their staff in a relatively strict and tough way.

After the LVI ${ }^{\circledR}$ we have applied DOCS as both a resource of information about organization's 1 culture and additional interpretative framework for understanding the meaning of versatility scores. The DOCS data (see Figure 8) are presented in two forms: (1) averages - average is calculated from the all 
ratings on a five point scale; generally "good" are the values 4 and above; (2) percentiles - they represent benchmark results based on more than 1000 organizations rated by DOCS; i.e. percentile 80 means that $20 \%$ of the companies in database have reached the same or higher score and $80 \%$ of companies reached the same or lower score on a particular index than an organization ,,at hand“".

\begin{tabular}{|l|l|c|c|}
\hline Trait & Index & Average & Percentile \\
\hline \multirow{4}{*}{ Involvement } & Empowerment & 2,93 & 7 \\
\cline { 2 - 4 } & Team orientation & 3,00 & 6 \\
\cline { 2 - 4 } & $\begin{array}{l}\text { Capability devel- } \\
\text { opment }\end{array}$ & 3,52 & 61 \\
\hline \multirow{5}{*}{ Adansistency } & Core values & 3,25 & 12 \\
\cline { 2 - 4 } & Agreement & 2,93 & 9 \\
\cline { 2 - 4 } & $\begin{array}{l}\text { Coordination \& } \\
\text { integration }\end{array}$ & 2,93 & 27 \\
\hline \multirow{5}{*}{ Mission } & Creating change & 2,96 & 23 \\
\cline { 2 - 4 } & Customer focus & 3,14 & 7 \\
\cline { 2 - 4 } & $\begin{array}{l}\text { Organizational } \\
\text { learning }\end{array}$ & 3,26 & 55 \\
\hline & $\begin{array}{l}\text { Strategic direc- } \\
\text { tion and intent }\end{array}$ & 3,43 & 53 \\
\cline { 2 - 4 } & $\begin{array}{l}\text { Goals and objec- } \\
\text { tives }\end{array}$ & 3,41 & 43 \\
\cline { 2 - 4 } & Vision & 3,10 & 45 \\
\hline
\end{tabular}

Figure 8. DOCS results for an organization 1

According to the averages themselves the culture of an organization 1 could be easily perceived as an ordinary and "normal" one. The percentiles thus offer us more valuable information.

Within a dynamic perspective a culture of organization 1 can be interpreted in the following way:

1. Tension between internal ("involvement" and "consistency") and external ("adaptability" and "mission") focus. In this respect it is obvious that organization's management pays much more systematic attention to the external circumstances and conditions than to a consolidation and effective management of the internal resources and processes (except of "capability development"). The first recommendation concerns a need to begin to pay a systematic attention the internal life of an organization.

2. Tension between stability ("mission" and "consistency") and flexibility ("adaptability" and "involvement"). Stable aspects of organizational culture are, (except of an "agreement" about important issues and a clear/explicit definition of the "core values") managed more effectively than phenomena and processes associated with both internal and external vitality (except of "capability development" and "organizational learning"). The second "warning" points to a need to define and implement rules, principles and policies which will make the organization flexible and ,ready for action“.
3. Tension between (internal) consistency and (external) adaptability. There is a plenty of room for a change and development in both of these areas of organizational culture. On a side of consistency the very low percentiles for indexes "agreement" and "core values" indicate that no clear rules and norms defining the areas of desirable/ appropriate and undesirable/inappropriate behaviour have been implemented yet. On a side of adaptability there are the warning signals that organization lacks a "customer focus" (possible reason is that most of its business have been mediated by a foreign "mother" before) and abilities associated with "creating change" (i.e. flexible working procedures, cooperation between departments, active seek for the new opportunities).

4. Tension between mission and involvement. On this level of an analysis a contrast between relatively well elaborated organization's mission and poor involvement of its employees (except of focus on "capability development") deserves our attention. Strategic visions, goals, intents etc. should be brought to life through an active participation of the employees on their definition and by the means of establishing cooperative relations and spirit across the whole organization.

It is possible to identify several interesting links between the LVI ${ }^{\circledR}$ and DOCS results. First of all organization's culture deficit in the area of "empowerment" correspond to the LVI® findings about imbalances on a dimension of directive VS supportive leadership - managers tend to base their leadership style on competencies associated with directive and self-assertive approaches at the expense of supporting, empowering and listening to their subordinates (see Figures 6 and 7).

The organization's culture deficits in the areas of "creating change" and "customer focus" can be related to the LVI® deficits in the area of competencies associated with strategic leadership, in particular orientation on growth (i.e. growing the business, personal will to take a risk, launching change initiatives) and directing an organization towards future (i.e. strategic thinking, long term-planning).

Organization's culture deficits in the area of team orientation correspond up to a certain degree with the LVI ${ }^{\circledR}$ finding concerning team effectiveness (this wasn't presented above). Six (6) out of nine (9) teams led by the rated managers were evaluated as the groups with relatively low effectiveness (below 50 percentile in a long term database) on both productivity (quantity and quality of outputs) and vitality (climate, commitment, cohesiveness) measures.

It is possible to say that DOCS data have not only mediated a useful feedback about organizations' culture but that they brought a new light on the LVI ${ }^{\circledR}$ results. LVI® results were originally presented as an information about the degree of personal versatility (strengths, deficits and excesses in the area of competencies) of the managers. It was mostly up on the individual managers if they accept this feedback and decide to change their behavior and attitudes. Illustration of the links between DOCS and LVI ${ }^{\circledR}$ help them to understand that a change and development of their management competencies is not their personal business but a need with important strategic consequences for the whole organization. After this insight 
organization's management has decided to prepare a workshop focused on a detailed elaboration of both individual personal development plans and a plan for a joint learning of the whole management group. They have also asked our research team to give them a new LVI ${ }^{\circledR}$ and DOCS feedback next year.

\section{Case 2: Organization producing packaging}

The second organization we have analysed was a Czech branch of an international company producing packaging. It employs app. 90 people and its top management is represented by 4 people. The company operates on a Czech market since 1997. Managers felt that they should substitute their rather spontaneous attitude to individual and organizational learning by a systematic approach based on an expertise.

Also here we started with an application of the LVI®. Average experience of these 4 managers with managerial position and work was 9, 5 years (minimum 4 years - director, maximum 20 - production manager). Figure 9 shows the average LVI® scores for the group.

\begin{tabular}{|l|c|c|c|}
\hline & $\begin{array}{c}\text { Overall } \\
\text { versatility }\end{array}$ & $\begin{array}{c}\text { Directive/ } \\
\text { supportive } \\
\text { versatility }\end{array}$ & $\begin{array}{c}\text { Operational/ } \\
\text { strategic } \\
\text { versatility }\end{array}$ \\
\hline $\begin{array}{l}\text { Group } \\
\text { average }\end{array}$ & $82 \%$ & $79 \%$ & $85 \%$ \\
\hline
\end{tabular}

Figure 9. Average versatility scores of the managers from organization 2

Similarly like in a case 1 also these data present the organization's management team versatility as neither ,excellent" nor ,poor".

The lowest score (79\%) was reached for a dimension Selfassertive, directive VS Inclusive, supportive leadership. This indicates again that probably the major challenges in the area of the management competencies development are associated with "how" the managers approach and lead their staff. This doesn't concern a (female) director, who scored $91 \%$ on this dimension. The other managers' scores were $73 \%, 75 \%$ and $76 \%$. A deeper insight into this area can offer us an overview of the major excesses (see Figure 10) and deficits (see Figure 11).

\begin{tabular}{|l|c|}
\hline Item & Frequency \\
\hline $\begin{array}{l}\text { 2f: Takes the initiative - seizes the oppor- } \\
\text { tunity to lead. (Takes charge) }\end{array}$ & $\mathbf{2}$ \\
\hline $\begin{array}{l}\text { 4f: Steps in - gets personally involved } \\
\text { when problems arise. (Takes charge) }\end{array}$ & $\mathbf{1}$ \\
\hline $\begin{array}{l}\text { 7f: Forthcoming - tells people what is on } \\
\text { his/her mind. (Declares) }\end{array}$ & $\mathbf{1}$ \\
\hline $\begin{array}{l}\text { 8f: Defend his/her position - doesn't back } \\
\text { down easily. (Declares) }\end{array}$ & $\mathbf{1}$ \\
\hline 9f: Pushes people hard. (Pushes) & $\mathbf{1}$ \\
\hline $\begin{array}{l}\text { 8o: Seek efficiencies - looks for ways to } \\
\text { contain or reduce costs. (Efficiency) }\end{array}$ & $\mathbf{1}$ \\
\hline
\end{tabular}

Figure 10. The major excesses within a management team of organization 2
Six (6) out of seven (7) major excesses represent a pole of Self-assertive, directive approach to people. When related to general areas of management competencies these results show that some members of the management team tend to "take charge" too much (as the opposite to competence of "empowering" people), tend to "declare" themselves too much (as the opposite to competence of "listening"), and tend to "push" people too much (as the opposite to competence of "supporting"). One manager is too much focused on efficiency (represents pole of operational leadership).

\begin{tabular}{|l|c|}
\hline Item & Frequency \\
\hline $\begin{array}{l}\text { 6e: Draws people out - wants to know } \\
\text { where they stand. (Listens) }\end{array}$ & $\mathbf{1}$ \\
\hline $\begin{array}{l}\text { 7e: Open to influence - can be persuaded to } \\
\text { change his/her mind. (Listens) }\end{array}$ & $\mathbf{1}$ \\
\hline $\begin{array}{l}\text { 9e: Shows appreciation - goes out of his/her } \\
\text { way to make other people feel good about } \\
\text { their contribution. (Supports) }\end{array}$ & $\mathbf{1}$ \\
\hline $\begin{array}{l}\text { 11e: Sensitive - careful not to hurt other } \\
\text { person's feelings. (Supports) }\end{array}$ & $\mathbf{1}$ \\
\hline
\end{tabular}

Figure 11. The major deficits within a management team of organization 2

All major deficits (4) represent competencies associated with supportive leadership. Members of the management team tend to be ( 2 cases) too little oriented on listening to people and ( 2 cases) too little focused on supporting the subordinates. In general the management tends to prefer the use of directive and self-assertive approaches at the expense of inclusive and supportive leadership. None of the strong deficits represents dimension operational - strategic leadership.

The DOCS data for organization 2 are presented in Figure 12.

\begin{tabular}{|l|l|c|c|}
\hline Trait & Index & Average & Percentile \\
\hline \multirow{4}{*}{ Involvement } & Empowerment & 3,20 & 22 \\
\cline { 2 - 4 } & Team orientation & 3,22 & 18 \\
\cline { 2 - 4 } & $\begin{array}{l}\text { Capability devel- } \\
\text { opment }\end{array}$ & 3,18 & 17 \\
\hline \multirow{4}{*}{ Consistency } & Core values & 3,48 & 36 \\
\cline { 2 - 4 } & Agreement & 3,05 & 20 \\
\cline { 2 - 4 } & $\begin{array}{l}\text { Coordination \& } \\
\text { integration }\end{array}$ & 3,04 & 38 \\
\hline \multirow{4}{*}{ Mission } & Creating change & 3,26 & 66 \\
\cline { 2 - 4 } & Customer focus & 3,35 & 28 \\
\cline { 2 - 4 } & $\begin{array}{l}\text { Organizational } \\
\text { learning }\end{array}$ & 3,23 & 51 \\
\hline & $\begin{array}{l}\text { Strategic direc- } \\
\text { tion and intent }\end{array}$ & 3,23 & 33 \\
\cline { 2 - 4 } & $\begin{array}{l}\text { Goals and } \\
\text { objectives }\end{array}$ & 3,40 & 43 \\
\cline { 2 - 4 } & Vision & 3,20 & 57 \\
\hline
\end{tabular}

Figure 12. DOCS results for an organization 2 
Also in this case the more valuable and reliable information's have been mediated by the percentiles.

Within a dynamic perspective a culture of organization 2 can be interpreted in the following way:

1. Tension between internal (involvement and consistency) and external (adaptability and mission) focus. Similarly like in a case 1 also here it is obvious that organization's management pays much more systematic attention to the external circumstances and conditions than to a consolidation and effective management of the internal resources and processes. Managers should no longer ignore the internal "affairs".

2. Tension between stability (mission and consistency) and flexibility (adaptability and involvement). Stable aspects of organizational culture are, (except of an agreement about important issues) managed more effectively than phenomena and processes associated with organization's flexibility.

3. Tension between (internal) consistency and (external) adaptability. There are at least two important topics for a change and development on this pair of opposites. On a side of consistency the very low percentile for index "agreement" indicates that no clear rules and norms defining how to behave in conflict and ambiguous situations have been defined and implemented yet. On a side of adaptability there is the warning signal that organization should increase its "customer focus".

4. Tension between mission and involvement. On this level of an analysis a contrast between relatively well elaborated organization's mission and poor involvement of its employees on all measured indexes is apparent. Managers, in particular those "under" a director, will have to change their approach and attitudes towards subordinates significantly.

What are the links between the LVI ${ }^{\circledR}$ and DOCS results in this case? The results of these two techniques correspond together in two respects at least. First, organization's 2 culture deficit in the area of "empowerment" (and maybe also in the area of "capability development") correspond to the LVI ${ }^{\circledR}$ findings about imbalances on a dimension of directive VS supportive leadership - as it was stated before members of the management team tend to base their leadership style on competencies associated with directive and self-assertive approaches at the expense of supporting, empowering and listening to their subordinates (see Figures 10 and 11).

Second, organization's culture deficits in the area of team orientation probably reflect to a certain degree the LVI ${ }^{\circledR}$ findings about team effectiveness. Three (3) out of four (4) teams of the rated managers were evaluated as the groups with relatively low effectiveness on both productivity (quantity and quality of outputs) and vitality (climate, commitment, cohesiveness) measures. As the only one effective was evacuated director's team (composed of the members of management team and administrative staff).

Also in this case the DOCS data have not only mediated a useful feedback about organization's culture but that they brought a new light on the LVI ${ }^{\circledR}$ results, in particular those associated with a direct management of the individuals and teams/groups.

\section{Discussion}

The data collection process was started in February 2013 and will continue till December 2014. The data available at the moment were collected in two organizations. As it has been stated before, they do not represent sufficient amount of information for a statistic analysis and for answering all of our research questions and working hypothesises. On the other hand our mainly qualitative analysis of these data enables us to formulate two preliminary conclusions:

- Some of our expectations (see research questions and hypothesises) about an existence of the relations between organization's management versatility as it is measured by the LVI ${ }^{\circledR}$ and organizational culture traits and indexes as they are measured by DOCS can be confirmed. Two cases presented above suggest that the LVI ${ }^{\circledR}$ results for a dimension "self-assertive, directive VS inclusive, supportive" leadership correspond, up to a certain degree, to the DOCS findings for and index "empowerment". In both of our cases/organizations also a possible correspondence between the LVI ${ }^{\circledR}$ results concerning "team effectiveness" and DOCS data for and index "team orientation" was indicated. We will propose a new working hypothesis on a basis of this finding. And, finally, case 1 shows that there can exist relations between the LVI® results for a dimension "operational VS strategic" leadership (in particular sub dimensions "growth" and "direction") and the DOCS data for the indexes labelled "creating change" and "customer focus". All of these suggestions need to be confirmed by a reliable statistical analysis based on data from more than two organizations, however.

- DOCS data can bring a new light on the LVI® results and, consequently on the process of management competencies development. Illustration and discussion of the links between DOCS and LVI ${ }^{\circledR}$ helped managers from both organizations to understand that a change and development of their management competencies is not their personal business but a need with important strategic consequences for the whole organization. In other words it became obvious that the process of management competencies development should be integrated with the efforts to create an effective and well-balanced organizational culture (and the opposite).

Our research team will start to collect new LVI ${ }^{\circledR}$ and DOCS data in a big company construction company. We also lead negotiations with the management of a big insurance company at the moment. Till December 2014 we plan to analyse approximately 8 more organizations. After analysis of all these data we will be able to give more qualified answers to our research questions and hypothesises.

\section{Acknowledgements}

The research project is supported by Škoda Auto University internal grant agency as project IGA/2012/7 "Versatility of Organizational Management and its Reflection in the Area of Organizational Culture“. Denison Organizational Culture Survey have been used with a permission and assistances 
(calculation of the percentile scores) by experts from Denison Consulting. The DOCS data and results are used exclusively for the research purposes.

\section{References}

Denison, D. et al. (2012). Leading Culture Change in Global Organizations. Aligning Culture and Strategy. San Francisco: Jossey - Bass.

Gatley, S., Lessem, R. \& Altman, Y (1996). Comparative Management. A Transcultural Odyssey. London: McGraw-Hill.

Hartnell, C.A., Ou, A.Y. \& Kinicki, A. (2010). Organizational Culture and Organizational Effectiveness: A Meta-Analytic Investigation of the Competing Values Framework's Theoretical Suppositions. Journal of Applied Psychology. 96 (4): 677 - 694, http://dx.doi.org/10.1037/a0021987

Hersey, P. \& Blanchard, K.H. (1993). Management of Organizational Behavior. Utilizing Human Resources. London: Prentice-Hall.

Hogan, R. (2006). Personality and the Fate of Organizations. New York: Psychology Press.

Holland, J. L. (1997): Making Vocational Choices. A Theory of Vocational Personalities and work environment. New Jersey: Prentice Hall.

Kaiser, R.B. \& Kaplan, R.E. (2007). Leadership Versatility Index ${ }^{\circledR}$ Facilitator's Guide. Greensboro: Kaplan DeVries Inc.

Kaiser, R. B. \& Kaplan, R.E. (2005). Overlooking Overkill? Beyond the 1-to-5 Rating Scale. Human Resource Planning, 28 (3): 7 - 11.

Kaiser, R.B., Overfield, D.V. (2010). Assessing Flexible Leadership as a Mastery of Opposites. Consulting Psychology Journal. 62 (2): 105 - 118, http://dx.doi.org/10.1037/a0019987

Kaplan, R.E. \& Kaiser, R.B. (2003). Developing Versatile Leadership. MITSloan Management Review. 44 (4): 19 - 26.

Kaplan, R.E., Kaiser, R.B. (2006). The Versatile Leader. Make the Most of Your Strengths - Without Overdoing it. San Francisco: Pfeiffer

Morgan, G. (1986). Images of Organization. London: Sage

Osland, J.S., Kolb, D.A. \& Rubin, I.M. (2001). Organizational Behavior. An Experiential Approach. New Jersey: Prentice-Hall

Padilla, A., Hogan, R. \& Kaiser, R.B. (2007). The Toxic Triangle: Destructive Leaders, Vulnerable Followers, and Conductive Environments. Leadership Quarterly, 18: 176 - 194, http:/ dx.doi.org/10.1016/j.leaqua.2007.03.001

Pavlica, K. et al. (2000). Sociální výzkum, podnik a management. Praha: Ekopress

Pavlica, K., Kaiser, R.B. \& Jarošová, E. (2009). Versatile Leadership, LVI and Their Application in Škoda Auto a.s. In Proceedings of the 9th International Conference Liberec Economic Forum 2009, (pp. 284 - 293), Liberec: Technická univerzita Liberec.

Pavlica, K., Kaiser, R.B. \& Jarošová, E. (2011). Versatile leadership, LVI and Their Application in Škoda Auto a.s. Chinese Business Review, 10(12): 1181 - 1190

Pavlica, K., Jarošová, E. \& Kaiser, R.B. (2010). Versatilni vedení. Dynamická rovnováha manažerských dovedností. Praha: Management Press.

Quinn, R.E. (1996). Becoming a Master Manager. A Competency Framework. New York: John Wiley and Sons

Whitmore, J. (2009). Koučování. Rozvoj osobnosti a zvyšování výkonnosti. 3. vydání. Praha: Management Press.

Yukl, G. (2013): Leadership in Organizations. $8^{\text {th }}$ ed. Cloth: Prentice Hall.

Karel Pavlica is a head of the Department of Managerial Psychology and Sociology on the Škoda Auto University in Mladá Boleslav, Czech Republic. He is teaching subjects focused on organizational and managerial psychology, crosscultural management and development of the social and managerial skills. He is an author and co-author of many papers and books related to the area of his professional expertise. During the last decade he conducted research projects in the areas of cross-cultural management, diversity management and leadership.

Eva Jarošová is working in the department of Managerial Psychology and Sociology on the University of Economics, Prague, Czech Republic. She is teaching subjects focused on psychology of work, managerial psychology, and development of social and managerial skills. She is active in the areas of professional coaching and psychological consultancy. She is an author and co-author of many textbooks and papers. Her research activities have been associated with leadership in a long-term.

Robert B. Kaiser is working in Kaiser Leadership Solutions, Greensboro, NC, USA which he formed in 2012. He coaches individual leaders and is specialized in helping high potentials prepare for senior leadership roles. He began his career at the Centre for Creative Leadership and joined the executive development firm, Kaplan DeVries Inc., in 1997. He was named partner in 2005. He is an author and co-author of many books and papers. 